\title{
How does career guidance at schools encounter migrant young people? Interactional practices that hinder socially just guidance
}

\author{
Sanna Vehviläinen ${ }^{1}$ (D) Anne-Mari Souto ${ }^{1}$
}

Received: 15 November 2019 / Accepted: 12 February 2021 / Published online: 9 March 2021

(c) The Author(s) 2021

\begin{abstract}
The aim of this article is to show how interaction research can contribute to the understanding and praxis of socially just guidance. The article is theoretical, but it makes use of our previous empirical studies. We combine the ethnographic study of school and racism, and interactional research on guidance. We define guidance for social justice, explaining how this translates to the level of interactional practices. We show two empirical examples of interactional phenomena hindering socially just praxis. We lastly discuss our practical conclusions on how to help school career counsellors change their interactional practices.
\end{abstract}

Keywords Guidance - School career counselling · Young migrant students · Guidance interaction · Social justice $\cdot$ Migration - Guidance for social justice

\section{Résumé}

Comment l'orientation scolaire et professionnelle dans les écoles approche-t-elle les jeunes migrants ? Pratiques interactionnelles qui entravent une orientation socialement juste L'objectif de cet article est de montrer comment la recherche sur l'interaction peut contribuer à la compréhension et à la pratique d'une orientation scolaire et professionnelle socialement juste. L'article est théorique, mais il utilise nos précédentes études empiriques. Nous combinons l'étude ethnographique de l'école et du racisme, et la recherche sur l'approche interactionnelle en orientation. Nous définissons l'orientation pour la justice sociale, en expliquant comment cela se traduit au niveau des pratiques interactionnelles. Nous montrons deux exemples empiriques de phénomènes interactionnels qui entravent les pratiques d'orientation socialement justes. Enfin, nous discutons sur la manière d'aider les conseiller-ère-s en orientation scolaire et professionnelle à modifier leurs pratiques interactionnelles.

Sanna Vehviläinen

sanna.vehvilainen@uef.fi

1 University of Eastern Finland, PO BOX 111, 80101 Joensuu, Finland 


\section{Zusammenfassung}

Wie begegnet die Berufsberatung in Schulen jungen Menschen mit Migrationshintergrund? - Interaktionelle Praktiken, die eine sozial gerechte Beratung behindern Ziel dieses Artikels ist es, zu zeigen, wie die Interaktionsforschung zum Verständnis und zur Praxis sozial gerechter Beratung beitragen kann. Der Artikel ist theoretisch, macht aber Gebrauch von unseren bisherigen empirischen Studien. Wir kombinieren die ethnographische Untersuchung von Schule und Rassismus und die Interaktionsforschung zur Beratung. Wir definieren Beratung für soziale Gerechtigkeit und erklären, wie sich dies auf die Ebene der interaktionellen Praktiken überträgt. Wir zeigen zwei empirische Beispiele für interaktionale Phänomene, die eine sozial gerechte Praxis behindern. Abschließend diskutieren wir unsere praktischen Schlussfolgerungen, wie man Schullaufbahnberatenden helfen kann, ihre interaktionellen Praktiken zu verändern.

\section{Resumen}

¿Cómo se desarrolla la orientación profesional en las escuelas con los jóvenes migrantes? - Prácticas interactivas que dificultan la orientación socialmente justa El objetivo de este artículo es mostrar cómo una investigación sobre interacciones puede contribuir a la comprensión y la práctica de una orientación socialmente justa. El artículo es teórico, pero se basa en nuestros estudios empíricos previos. Combinamos el estudio etnográfico sobre la escuela y el racismo, y la investigación interactiva sobre la orientación. Definimos la orientación para la justicia social, explicando cómo se traduce en el plano de prácticas interactivas. Mostramos dos ejemplos empíricos de fenómenos de interacción que obstaculizan la práctica de la justicia social. Por último, se presenta una discusión sobre la forma de ayudar a los orientadores educativos para que modifiquen sus prácticas interactivas.

\section{Introduction}

"It's not a question about what I am interested in, but rather where I will be accepted". This quotation from a young Somali boy living in Finland, as well as many recent empirical studies, show that racism and gendered occupational images narrow migrant young people's perceived options when they are considering their future plans. Racism and gendered and racialized vocational images (for instance, the category of a white Finnish working man as a prerequisite to be accepted as "a real builder") have been shown to cause young migrant people to drop out from vocational studies (Souto, 2016). Moreover, research shows that migrant young people have the lowest rate of utilizing mental health and other supportive services in schools (Kerkkänen \& Säävälä, 2015). This is paradoxical, considering the experiences of racism and other difficulties they have endured in both Finland and their country of origin or during the refugee journey (Honkasalo et al., 2017).

In the light of this, it is alarming that several studies have shown that career counsellors are hesitant, even reluctant to intervene in the ethnic, racialized and gendered division in educational transitions in Finland (Krivonos, 2019; Kurki, 2019; Souto, 
2016). In Souto's ethnographic study about school career counselling amongst migrants and unaccompanied minor asylum seekers, career counsellors recognized the ethnical, racial, and gendered segregation of secondary school choices amongst students. However, they were reluctant to raise these issues with the students. In addition to racism and discrimination, migrant history (for instance, routes to Finland) and diasporic family relations were examples of "dreaded topics" for career counsellors. This was the case even though family relations were a regular topic of discussion with other students. This contradiction, and especially the absence of certain relevant but avoided topics in counselling encounters (Souto, 2020), was the motivation for focusing on the micro processes of guidance.

The aim of this article is to show that interaction research can contribute to the understanding and praxis of socially just guidance. We claim that micro-interactional perspectives (analysing interaction closely from recordings or ethnographic data) should be incorporated into analyses of guidance within the social justice approach. Furthermore, the social justice approach should help practitioners to become aware of their interactional practices and redesign them. The focus of the article is theoretical, but we refer to our empirical studies and observations to argue for our perspective. We have combined two approaches: the ethnographic study of school and racism, and the interactional research on guidance as a social activity. We draw from Vehviläinen's interactional work in conversation analysis (for instance Vehviläinen, 2001, 2003, 2009a, 2009b, 2012), Souto's ethnography and interview data at schools in multicultural environments (Souto, 2016, 2020) and our current joint work in a developmental project amongst teachers and school career counsellors (Vehviläinen, 2020). Our aim is to develop guidance and counselling to embrace social justice in concrete ways that can be applied in everyday guidance interactions.

In the following, we first locate guidance as an activity in society, positioning our analysis in the social justice movement. Then, we provide our definition of guidance as a critical activity and explain what this means on the level of interactional practices. We suggest points in interaction where the workings of power could be detected. We then discuss two phenomena that present a recurrent hindrance to inclusive, critical guidance praxis. The first phenomenon is the dominance of socalled problem-solving orientation in guidance, and the second is the sidelining of "dreaded topics" such as racism and diasporic family relations. We find these to be amongst the key phenomena that shed light on critical issues concerning the possibilities of providing socially just and culturally sensitive guidance for critical populations in our society.

\section{Towards societally conscious guidance praxis}

The current mainstream approach in career guidance and counselling in Finland is the life design approach (for this approach, see Savickas et al., 2009). Whilst emphasizing the contextual and construed nature of an individual career, as well as various potentials for supporting individuals' career orientations and activities, there are shortcomings in terms of embedding existing knowledge of intersectionality and mechanisms of segregation. Its focus being on the individuals shaping 
their lives, this approach does not help to analyse how societal structures and unequal power relations shape individual dispositions and structures of opportunity, nor how these matters could figure into the interaction (Hooley et al., 2018).

On the other hand, critical analyses are plentiful within critical youth studies and critical studies of adult education (Aaltonen et al., 2017; Brunila, 2013). However, on their part, they lack concrete recommendations on how guidance or other such activities should be carried out to foster young people's agency and hope. In our earlier paper (Vehviläinen \& Souto, 2018) we analysed the paradoxes of these prevailing discourses; and suggested what a critical-but-practical theory of guidance should entail. Such a theory would need to operate on vocabulary that is not derived from the discourse of economy and qualifying function assigned to guidance in neoliberalism. It should embrace both individual and social values and aims, e.g. the aim of guidance towards the "individual's good" as well as the "collective's good" (Sultana, 2014). It should address societal, cultural, and intersectional (Crenshaw, 1989) mechanisms of social inequality as well as the dynamics of building both individual and collective agency; it should explicate how these theoretical notions make a difference in the concrete practices of guidance.

The recent developments within the promising social justice approach emphasize the need to analyse and problematize power relations and unequal societal positions and life courses (i.e. Hooley et al., 2018, 2019a). This approach also emphasizes the responsibility of career guidance to develop both the individual and community capacity to analyse societal inequalities, to build solidarity and to create new and shared opportunities. In practice, this means that spaces of collaborative activity must be created (Hooley et al., 2019b). They should be societally conscious, and enable individuals, groups, and networks to explore their possibilities of action, participation and belonging; to engage collaboratively in change-conducing activities. These spaces would enable individuals to participate in various collectivities, to recognize and inquire about their memberships and identities as well as rejections and exclusions-instead of resorting to stereotypical assumptions about them or treating them as blind spots.

There are various ways in which our institutional encounters could be redesigned and re-located towards more socially just aims; for instance joining multi-professional teams together to serve young clients in one-stop centres (Määttä, 2019) or taking counselling services to where the clients are (Thomsen, 2012). However, we feel it is necessary to also bring the analysis to the level of existing-perhaps traditional-interactional practices which construe and carry the agendas and values of the existing guidance. Our work takes place in institutional settings (in this case, school) where changes must be made "on the run". We are therefore interested in identifying steps that can be taken by the practitioners themselves-changes of mind and activity. That is why we want to focus on what happens in dyadic situations where the school career counsellors and students meet.

We draw from the social justice approach to guidance, but we bring in two new angles. Firstly, we theorize guidance from a cross-contextual point of view, as a generic family of practices (therefore the term "guidance" is used as an umbrella term). Secondly, we focus on the level of interaction. We have been guided by the 
question: What recommendations would socially just guidance offer to the interactional practices of guidance encounters?

\section{What is guidance as an activity}

In their second reader on social justice and guidance, Hooley and colleagues encourage us to redefine the problems that guidance is trying to solve: the unsteady economy or social inequality in societies (Hooley et al., 2019b). Guidance is often theorized by reference to the problem it seeks to solve-work, learning, career, integration, resettlement of refugees and other migrants, workability, well-being and so on. The call for re-theorizing typically stems from the changes in our understanding of the object of guidance activity. Our way of looking at the issue is somewhat different. We are interested in guidance as a generic phenomenon across contexts. Guidance is a family of practices across various institutions. It is also an approach within other professional practices. Guidance as an approach is used in, for instance, teaching and training, social work, leadership, integration work, rehabilitation, and health promotion (Vehviläinen, 2014).

Guidance as a set of institutional activities has gained an intensive role in the management of careers and life courses in postmodern societies (Brunila, 2013; Hooley et al., 2018; Romito, 2019; see also Cameron, 2000; Giddens, 1991; Rose, 1999). That is why it has been essential to understand how guidance has functioned as a control mechanism across neoliberal policies. However, the activity of "guiding" is a much older phenomenon-and essentially, of pedagogical nature. It is the activity and process whereby humans help and support each other, collaborate in their attempts to live their lives, try to understand the world around them, to find out what is true about it and what to do according to these truths (Alhanen, 2013, 2019; Dewey, 1916; Laros et al., 2017) This is the core process in any guidance. It is also necessary in any kind of progressive change in society. The relationships where this processual activity (of understanding and acting upon our world) takes place, are fundamentally pedagogical by nature. And, consistent with other pedagogical activities and relationships, guidance has the potential to develop into either controlling and repressive or to emancipatory, liberating forms. We are interested in the conditions under which guidance can gain its emancipatory potential.

We define guidance as a set of institutional, collaborative activities which promote and foster processes that are meaningful for the client(s); those of learning, growth, emancipation, work, leisure or other activity. This is done in such a way that the participants' agency and participatory sense are strengthened. The focal processes are viewed simultaneously as biographical, social and societal, and understood intersectionally (Souto \& Vehviläinen, 2019; Vehviläinen, 2014; for agency see also Eteläpelto et al., 2013; for participatory sense Alhanen, 2019).

This is the generic model of guidance activity (Vehviläinen, 2014). The objects of guidance activity (e.g. the topics or the foci of attention) can address various life situations, paths, aspirations, problems, conflicts, or challenges. Guidance is never the only_or even main - force shaping these processes. It is rather a space for inquiry about how these processes are constructed and negotiated in the clients' lives. 
By institutionality, we refer to the institutional location and attachment of guidance (school, work life, career transition, integration, health care, rehabilitation, employment), as well as to the professional nature of the guidance work and intervention. Institutionality refers also to conceptual tools, norms and rules and divisions of labour within and across activity systems. It also entails the boundaries and mediated spaces between the individual lives and institutions.

Guidance activities should be geared at strengthening the participants' agency. Guidance aims at systematic support of agentic participation in a relevant social context (such as school) and a biographical context. This movement towards stronger agency may manifest in changes in individual dispositions (abilities, interests, motivation, self-efficacy, resilience, skills, understanding); social participation via authorship, responsibility, creativity; and critical awareness, activity, and activism. These changes are unique to individuals and their situation, but they are not treated as individualistic phenomena. Guidance is fundamentally a relationship of pedagogical nature. Participants of this relationship seek to understand what is true about the world and themselves as part of it: asking how they have been shaped by the world-and how the world is shaped by them and others. For this reason, we stress that guidance aims at deepening the participatory sense (Alhanen, 2019). It applies to all parties of the guidance alliance.

For instance, the school career counsellor's task might be to understand the kind of role parents and other relatives, friends and the attitudes that prevail in society, play in the lives and career reflections of young migrant students, instead of just offering choices"likely to work out" or insisting that it should be their"autonomous choice". Or, in preparation of work placements, the school career counsellors should enable discussion about the risk of illegal but recurring racism at workplaces, including discussion on what to do when encountering it.

Guidance ought first and foremost to be engaged with the client's situation. The starting point of the joint activity is to understand their situation from their own perspective. The objects of the joint activity (i.e. the topics that are raised) should be those that are relevant to the client and resonate with their situation. What counts as relevance, though, is a question that requires further examination. The idea of letting "the client's meanings" guide what gets topicalized in the guidance talk, sometimes leads to a shallow type of client-centredness-i.e. a sort of ban on raising any issues other than those the client has nominated in so many words, and thereby actually disregarding difficult (often societal) topics of importance. We will discuss the idea of topicality later in the paper.

As Rie Thomsen (2012) has suggested, one of the consequences of the social justice approach is that the subjects of guidance activity must be reconceptualized (see also Vehviläinen, 2014; Vehviläinen \& Löfström, 2016). Not only individuals "do guidance", but also groups or teams, communities, and networks are the subjects of guidance activity. For instance, in guidance of young migrant students, one relevant aspect is to view the group of students as a guidance environment and to systematically build the group dynamics in the classroom, to create and sustain a safe and open learning environment. The success of critical guidance lies in the collaborative nature of the activity; without it, guidance loses its legitimation. The guidance relationship_be it between two people or more-is an alliance (Safran et al., 2007). 
The collaborative nature of any endeavour is a methodical achievement and takes place through the micro details of interaction. Guidance interaction and a pedagogical environment that will enhance agency and participatory sense entail negotiation, dialogue, and inclusive language.

Another prerequisite of maintaining the guidance alliance is openness and explicitness about potential multiple agendas and institutional relevancies, and about various asymmetries between participants. In institutional settings, there are always asymmetries, tensions, privileges, complexities, and multiple interests between participants. Instead of sticking to a concept of neutral guidance, these asymmetries should be explicated and explored. Otherwise they will have implicit bearings on the interaction. This is shown, for instance, in how the agenda is formed in the openings of the encounters (Svinhufvud \& Vehviläinen, 2013; Vehviläinen, 1999) or how question-response-advice sequences gear talk towards counsellor-led talk where both problem-identification and problem-solving are carried out by the counsellor (Vehviläinen, 2001, 2003, 2012).

Guidance is also dependent on understanding the key processes and their connectedness to life history and societal power structures. For instance, with young migrant students, one might need to consider the intertwining of developmental and integration processes, learning processes, group processes and work processes. And in line with this, guidance must be ready to focus on relevant objects of inquiry (i.e. the phenomena that are topicalized in interaction). Relevant objects are those that the clients orient to as relevant, but also those that bear upon their situation and enhance or hinder their agency, even if they are not articulating them.

\section{Studying power in interaction: the interaction research approach}

In our research, we wish to ask the following question: If guidance would take a turn towards societally and intersectionally conscious practice, what would guidance interactions look like? The generic model of guidance (Vehviläinen, 2014) that we discussed in the prior section builds on a longstanding body of research on guidance and counselling interaction in various settings (Vehviläinen, 2001, 2003, 2009a, 2009b, 2012; Vehviläinen et al., 2008; Vehviläinen \& Svinhufvud, 2018; Weiste et al., 2018). The model draws upon the approach of conversation analysis (CA) and the body of CA knowledge concerning institutional interaction (see e.g. Sidnell \& Stivers, 2012); especially literature on counselling and psychotherapeutic settings (e.g. Peräkylä et al., 2008) and application of these findings to the study of guidance as a social activity.

CA views multimodal interaction as an "institution in itself". Interaction is an order on its own right. As such, it is susceptible to empirical analysis (Sidnell \& Stivers, 2012). CA investigates recordings of naturally occurring interactions to uncover the practices of interaction through which the meanings of social actions are construed by the participants themselves in their turn-by-turn activities (Schegloff, 2007). Such analysis "takes apart" what the participants have put together: the sequentially organized activities (via talk and nonverbal communication) that accomplish encounters such as guidance. Such analysis remains "agnostic" in 
terms of the professional theories (for instance counselling theories or other normative views), but the research results can enter in a fruitful dialogue with professional theories (Peräkylä \& Vehviläinen, 2003).

The CA approach to interaction has produced a cumulative body of knowledge on how interaction is organized in a turn-by-turn fashion, to accomplish various institutional activities, identities; how power is exerted and resisted and how positions are taken and ascribed in interaction. CA studies, not only interactional practices, but also overarching principles that organize our activities in an omnirelevant way, often escaping the participants' observations. For instance, the epistemic organization, i.e. how knowledge, entitlements and orientations to knowledge and knowledgeability shape interactions and participation in particular context; and the deontic organization, i.e. how entitlements and orientations to influencing actions of others shape interactions and participation (Sidnell \& Stivers, 2012; Stevanovic \& Peräkylä, 2012).

Power relations are maintained but also changed through interactional practices. In an earlier paper by Vehviläinen (2018), six focal points were suggested, originating from $\mathrm{CA}$ research, for detecting power in guidance interaction:

1. Process: sequences and trajectories of talk (sequence being, for instance, a pair of question and its response: trajectory for instance a package of question-answeradvice, used to incorporate institutional agendas). In analysing sequential talk, we look at how participants of an institutional setting systematically influence the activities and participation of others and shape the course of action towards its institutional relevancies (for instance Vehviläinen, 2012);

2. Outcome: how the outcome of the institutional activity is produced through participation in sequential activities - and what outcome that is (for instance Vehviläinen, 2001);

3. Topicality: what topics are addressed, and how topicality is controlled by participants and by whom. The focus may be on delicate, difficult or "dreaded" topics (Peräkylä, 1995); on agenda and its transparency (Vehviläinen, 1999) but also on how the client's concerns are worked into an object of joint work-and to what extent it is actually shared (Antaki et al., 2005; Pälli \& Lehtinen, 2014; Vehviläinen \& Svinhufvud, 2018);

4. Studying absences: what is not topicalized, what objects of attention are disregarded, what does not surface at all; what actions or orientations are missing (for instance, Wilkinson \& Kitzinger, 2003);

5. Identities in talk: how identity categories are used, ascribed or implied (Stokoe, 2012); and

6. Misalignment, misunderstanding and conflict, and the management and repair thereof (Vehviläinen, 2008, 2009b).

We will now discuss two interactional practices, namely the prevalence of problem-solving activities in guidance (points 1 and 2 above), and management of topics in guidance encounters, especially those that are not raised (points 2, 3 
and 4 above). The points 5 and 6 are relevant and occurrent in our data, too, but these discussions will be left to other arenas.

\section{Problem-solving orientation as the prevailing interactional mode in guidance}

The interactional "fingerprint" of guidance can be identified by comparing it to two cognate practices. According to Vehviläinen's analysis (2014) based on a body of conversation analytic literature, interaction in guidance settings is a combination of two formats: the service encounter and the therapeutic encounter. Service encounters are organized according to the expectation that the clients present their problems via narratives or trouble descriptions, and the professional will tackle these problems with their knowledge. This happens in the interaction through their directive interventions: recommendations, advice, and information, which are delivered upon hearing the client's narrations. Thus, there is a prominent problem-solving orientation in service encounters.

Therapeutic encounters, on their part, are centred around inquiry (explorative) orientation. Clients present their problems and narrate their experience. Instead of providing solutions, the professionals invite the clients to explore and understand the material they have produced (the narrations of experience) as an expression of a more fundamental pattern or cause, which is to be uncovered or constructed together. Thus, it is a process of co-exploration. Instead of advice or recommendations or other directives, the professional engages in interpretative talk, providing formulations (summaries) and interpretative statements and suggestions. The clients are invited to discuss their experience on distinct discursive terms, according to the therapeutic or counselling approach. There are also prominent displays of affiliation to the emotional content of the clients talk, thus, a supportive orientation (Peräkylä et al., 2008; Vehviläinen, 2014; Voutilainen et al., 2010; Weiste, 2015; Weiste \& Peräkylä, 2014).

Guidance work, in its various forms (e.g. guidance, counselling, supervision, mentoring), typically uses interactional practices of both the service encounter interaction and the therapeutic encounter. Thereby, the abovementioned three core interactional orientations fluctuate in guidance encounters. We contend that it is essential for emancipatory practice that these orientations are recognized, mastered and timed skilfully.

The supportive orientation refers to both verbal and nonverbal work that is done to facilitate joint attention and activity, to face the "situation as it is," (or how it seems at the moment) along with the emotional reactions to it; and to convey support-e.g. interest, acceptance and affiliation. In the supportive orientation, the professionals show that they are present to the clients and attentive to what is going on; that they are mentally and emotionally available and willing to receive what clients share about their reality. Thus, the supportive orientation is the embodied display of presence, attentiveness, and affiliation, and often this takes place by nonverbal cues along with verbal attentiveness (such as minimal response tokens to convey listening). 
The inquiry orientation refers to exploring the clients' experiences, situations, problems or challenges or any other joint object of inquiry, diversifying the picture, and eliciting multiple interpretations. In inquiry orientation, in-depth observation and reflection is considered valuable as such, as it increases understanding both "inwards" and "outwards". Deepening of understanding itself is a prerequisite to new awareness or emancipation. This orientation, then, is necessary to fostering critical reflection. It is also necessary in gaining a critical view of the client's opportunity structures in the education and labour market. As Hodkinson and Sparkles (1997) have stated, horizons for action are based both on structural possibilities (in the school market, labour market, etc.) and the habitus. Habitus refers to the individual's socially and culturally bounded dispositions (ethnicity, gender, class, sex) that strongly affect young people's decisions, aspirations and what they consider possible and attainable.

The problem-solving orientation, especially via giving advice, is shown by many studies to prevail in forms of guidance, especially in career guidance and study guidance (Butler et al., 2010; Emmison et al., 2011; Kinnell \& Maynard, 1996; Pudlinski, 2012; Silverman, 1997; Strong \& Baron, 2004; Vehviläinen, 2001, 2003; Vine et al., 2012; Waring, 2005, 2007, 2012). In this orientation, problems are meant to be solved-often relatively timely_and the professionals mobilize their own expertise to find solutions. These solutions are communicated to the client typically by advice, suggestions, recommendations or in certain settings, feedback (Vehviläinen, 2009b). In Vehviläinen's studies in career guidance training in the 1990s, the analysis showed that there was a strong problem-solving orientation, using advice as the pro forma intervention to tackle any issues raised in the counselling encounters, and making sure the expected result (the action plan) was produced (Vehviläinen, 1999). Also, according to numerous reports from our training groups, many guidance professionals feel that their practice "slips" towards this orientation even when they do not intend that, or when the counselling approach directs them not to give advice.

When problem-solving orientation is the un-reflected default format, the practices of interaction have a tendency toward pushing the discussion towards problem-solving activities (instead of staying in the supportive or inquiry orientation) and un-reflected goal-orientation (instead of negotiating diverse goals or rationales). Thereby, relevant issues of identity and social realities may be overlooked.

This tendency is recurrent in various fields of guidance, despite the recommendations of various guidance or counselling theories (for a summary, see Vehviläinen, 2012, 2014) and it has prevailed for decades, despite longstanding critical discussion. The reasons for this are perhaps threefold. Firstly, they are ideological, in that the neoliberal strategies in guidance institutions press professionals to demand particular, pro forma outcomes within a tight time frame. Secondly, there are interactional reasons that can be learned about through conversation analytic research. The structures of interaction may work towards the service encounter and rushed problem-solving by professionals. For instance, if the student comes in with a question, and the counsellor has knowledge of the answer, it requires interactional work to not respond right away and not to let the encounter develop into a service encounter. Thirdly, there are expertise-related 
reasons as guidance professionals may not have recognized these mechanisms nor have tools to design their talk-in-interaction differently.

Problem-solving is, of course, a necessary part of many guidance situations. It is relevant to see what can be done, to act in new ways and to collaborate in experimentation. As it stands, however, the problem-solving orientation in guidance has various shortcomings. There is the abovementioned pressure towards a narrow, pre-defined institutional goal, without checking mutual understanding and different interpretations. This may cause participants to hurry to solve problems which are not relevant, profound, or meaningful, or which are not connected to the biographical or societal elements that hinder or strengthen the client's agency. Importantly, there is also the tendency to not engage the client in constructing the problem or the solution (Vehviläinen, 2012), which from a pedagogical point of view, is not useful in developing agency.

The prevalence of the problem-solving orientation was also observed in Souto's fieldwork at schools. Career counsellors tended to concentrate on issues that they feel they can "fix", solve or name: for instance, pupils' lack of competencies, language skills or special support needs in studying. Of course, these issues may be relevant to the young migrant students, but the way these "convenientfor-counsellors" issues dominated the encounters caused the complex, difficult and serious issues to be treated as marginal ones. In some schools, there were even regulations and guidelines for counsellors not to ask migrant students about difficult issues, as the next excerpt shows:

Many (migrant students) have really difficult backgrounds and we are used to not to ask about backgrounds. Okay, we ask "which country did you come from and how long have you been in Finland", but we don't start digging into "why you came, what has happened" or stuff like that. Students will share this information if they want to...

\section{a career counsellor, vocational studies}

The dominance of problem-solving orientation, then, is a default model that counsellors are likely to choose for ideological, emotional and interactional reasons, unless they become conscious of these micro practices of interaction and learn about other ways of conducting the encounter. Furthermore, clients are also often likely to select such orientation. Guidance clients often approach the guidance professionals with relatively narrow, information-seeking questions. This is what they often treat as their responsibility: to have something to ask the professional (Vehviläinen, 2009a). However, after the onset of the encounter, more complex issues typically surface. Even in situations where there are no difficult or "dreaded" issues at hand, it is typical that the issue gets re-framed and diversified in the course of the talk. Not only do participants identify "answers" but they first end up re-writing the questions together. Thus, it seems generally useful to leave space for an inquiry orientation to develop and not routinely "do the service-encounter". 


\section{"Dreaded topics" in guidance of migrant young people}

According to Souto's analyses (Souto, 2020) but also our training experience amongst counsellors, teachers, and school leaders and other school professionals, the school staff recognize that young migrant students face inequality, exclusion, and various problems in the way their paths unfold in society. Our next excerpt shows this:

Oh, then I made a mistake and asked: "how about your parents, how are things going with mom and dad, and could you tell me something about your family", and then... He was just... half of his family had been killed in front of his eyes. Then I was like... uhm, "how about the schooling background of your parents?"... I can't handle, or I have not found a way to react and discuss these things. I have come to the conclusion that I won't ask about family in the first meeting. I think that it is not so important to be so curious... They presumable have been asked that several times so... so... But of course, sometimes they tell you that their parents are dead, then you are of course sorry for that, that's very unfortunate and so on, but I don't address these issues because I am not a social worker or a psychologist who can somehow find the right words. I'm not going to ask about family anymore.

\section{a school career counsellor}

This quotation from a research interview of a school career counsellor, shows how counsellors emphasize the problem-solving orientation over other orientations. In effect, the counsellor does not seem to believe in the importance of supportive orientation. In other words, they do not believe that active listening to their clients' troubles - thereby witnessing some aspect of their reality-would be enough. It seems easier for the counsellor to concentrate on "solvable" problems such as study choices or language skills. Furthermore, counsellors often attribute these supportive interventions to other professionals, as someone else's mandate. This way, the counsellors end up communicating to the students that they are not ready to encounter certain parts of their reality.

One crucial consequence of the limited use of supportive orientation is that young migrant people are left alone to deal with their past and the way it links to their future plans. They themselves must raise these issues if they wish for them to be addressed in guidance encounters. This would require a lot of courage and agency. As many studies have shown, such self-directedness and strong agency may be too much to expect. Young migrant people, especially those who have arrived as asylum seekers on their own, are left alone to deal with their difficult experiences in building their new life in Finland (Honkasalo et al., 2017; Souto, 2020). This way, a relevant aspect of the guidance alliance is left incomplete, and the cohesion of the guidance relationship may remain low.

Another consequence of the limited use of both supportive and inquiry orientations is that the relevant issues of young migrant peoples' social realities, past and present, are excluded from the guidance interaction. Especially, the diasporic 
nature of family (including family members here and there, alive or dead) and the migration history (i.e. the journey to Finland) are recurring examples of such "dreaded topics", but also racism and other forms of inequality are amongst these.

The next excerpt shows that career counsellors do recognize the meaning of the family relations behind the young people's different choices. However, the way young people value and consider their parents' and relatives' views and hopes are often interpreted as wrong, or not respected. Young migrant people are expected to make their decisions individually and follow suggestions or expectations of their families.

There are always the family's hopes and views behind the migrant youth's decisions, but I think it is the counsellor's duty to begin with the young people as an individual, what is the best for them and what are their deepest hopes and aspirations. This is the way in which an individual can be free. Because I totally believe that everything will go fine if everyone finds their own thing.

a school career counsellor

This demand for making your own autonomous choice- "finding your thing" as the expression goes - can be interpreted as a prerequisite not only for the right kind of choice-making but even for the guidance process itself (Souto, 2020). Thereby, it is a way of shaping the possibility to participate in the guidance interaction as well as its outcome. Young people are expected to be able to present and argue their choices in the guidance encounter as autonomous and free from others' opinions. Many scholars have shown, in both Finland and elsewhere that such practices demanding young people to be autonomous and individually responsible for their choices are the central discourses in pursuing and producing entrepreneurial subjects who can manage by themselves the transitions in education and the labour market in the current economic context (Brunila, 2013; Romito, 2019).

Moreover, this demand for making your own, autonomous choice is also "a platform" for othering the Other culturally. The family centred way of life may be viewed as problematic and as a threat for the culturally "right" kind of choice-making in the Finnish context. This biased way of reacting to young migrants' (especially girls) family relations (or religious convictions) is one of the main reasons why young migrant people choose not to bring up family issues, either positive or negative, in counselling encounters. This biased atmosphere at schools and in guidance settings constitutes a hindrance for young people to topicalize their experiences or fears of racism and other forms of discrimination. To summarize, the discourse of "the autonomous choice" is a central medium to conceal the socio-cultural underpinnings of educational and life trajectories, leaving undebated and unquestioned the process that allows inequalities to be produced and reproduced within the educational and guidance systems, as Romito (2019, p. 110) has argued. 


\section{Conclusion: recommendations for guidance interaction for social justice}

We view guidance as a space where participants learn about reality together. In the professional role, the guidance professional-the career counsellor at school-is open about various asymmetries between participants and is ready to learn from the student and their situations. We have examined two aspects of guidance interaction that we found to hinder career counsellors' possibilities to engage in critical, societally conscious and emancipatory guidance at school with their migrant students: the overemphasis on problem-solving orientation, and the 'dreaded' difficult topics. We now wish to make conclusions about our findings with respect to how we can help school career counsellors overcome these hindrances. We have tried to apply our understandings in ways that could be directly made use of in training situations.

First, it is particularly important to learn about one's own privilege (for instance, as a white, native, heterosexual, middle class person) and to understand one's own emotional reactions (i.e. guilt, sorrow, fear, shame, helplessness) that occur in these learning situations. Introspection in collegial spaces is needed for this: living with the imperfection of the self. This is the inevitable price of changes in guidance professionals' own participatory sense.

It is also necessary for guidance professionals to accept that supportive orientation is a professionally sound and ethical response to students' situations and the realities they bring into guidance. It is good professional conduct to discuss the difficult issues students wish to talk about-such as experiences of oppression or dispersed and diasporic family relations-even if these issues may not be "solvable", or within the guidance professionals' institutional mandate.

Furthermore, school counsellors need experiences of being engaged in collaborative inquiry about difficult topics, being respected as professionals and supported whilst showing their vulnerability and uncertainty. Only then they are able to provide such supportive, reflective experiences to their students. Upon experiencing such collegial support, they can also become curious about methods of supportive and inquiry orientations. They can also become creative in designing ways to engage their students in guidance in such a way that it strengthens their agency and participatory sense. Our experiences in school developmental projects have provided promising results towards this direction (Vehviläinen, 2020).

Client-centeredness and respecting the client's meanings and experience as a starting point of the working relationship is perhaps the most common principle of numerous guidance approaches. We also believe this to be true. However, we contend that this should not be interpreted as a ban on mentioning any other topics than those that the student has named in so many words. Some topics like segregation and racism take courage and trust to raise, and students also screen the professionals at school to feel out whether they would be likely to listen and be able to handle their stories. Thus, we want to state that critical or socially conscious guidance relies, not only on active listening, but also on the professionals' knowledge about power structures and mechanisms. Thus, they can anticipate and 
sensitively make room for topics that could be relevant and helpful. They can also have the courage and creativity to "name the oppressor" (Hooley, 2019, 2019b). For this, they need a new methodology for supportive, inquiry-based orientation and patience to sometimes wait for the right moment, both in dyadic situations, but also in group settings.

Guidance practices cannot work in emancipatory ways without a working alliance between the participants of the guidance relationship. No matter where the critical gaze is directed, a trusting and safe relationship must be established amongst the participants. It may not be on the student's own explicated agenda to engage in critical analysis of society, but a guidance encounter should make this possible. The gateway to this kind of meaningful encounter is through genuine interest in hearing what the client has to say and how they experience their situation. The institutionally expected outcome (for instance students making study choices at school) has its place, but these expectations should not colonize the interaction.

Funding Open access funding provided by University of Eastern Finland (UEF) including Kuopio University Hospital.

Open Access This article is licensed under a Creative Commons Attribution 4.0 International License, which permits use, sharing, adaptation, distribution and reproduction in any medium or format, as long as you give appropriate credit to the original author(s) and the source, provide a link to the Creative Commons licence, and indicate if changes were made. The images or other third party material in this article are included in the article's Creative Commons licence, unless indicated otherwise in a credit line to the material. If material is not included in the article's Creative Commons licence and your intended use is not permitted by statutory regulation or exceeds the permitted use, you will need to obtain permission directly from the copyright holder. To view a copy of this licence, visit http://creativecommons.org/licen ses/by/4.0/.

\section{References}

Aaltonen, S., Berg, P., \& Karvonen, S. (2017). Affordances of welfare services-perspectives of young clients. Nordic Welfare Research, 2(1), 30-38. https://doi.org/10.18261/issn.2464-4161-2017-01-04

Alhanen, K. (2013). John Deweyn kokemusfilosofia [The philosophy of experience of John Dewey]. Gaudeamus.

Alhanen, K. (2019). Dialogue in democracy. Books on Demand.

Antaki, C., Barnes, R., \& Leudar, I. (2005). Diagnostic formulations in psychotherapy. Discourse Studies, 7(6), 627-647. https://doi.org/10.1177/1461445605055420.

Brunila, K. (2013). Hooked on a feeling: Education, guidance, and rehabilitation of youth at risk. Critical Studies in Education, 54(2), 215-228. https://doi.org/10.1080/17508487.2012.716369

Butler, C., Potter, J., Danby, S., Emmison, M., \& Hepburn, A. (2010). Advice-implicative interrogatives: Building "client-centered" support in a children's helpline. Social Psychology Quarterly, 73(3), 265-287. https://doi.org/10.1177/0190272510379838

Cameron, D. (2000). Good to talk? Sage.

Crenshaw, K. (1989). Demarginalizing the intersection of race and sex: A black feminist critique of antidiscrimination doctrine, feminist theory, and antiracist politics. University of Chicago Legal Forum, 140, 139-167. https://chicagounbound.uchicago.edu/uclf/vol1989/iss1/8.

Dewey, J. (1916). Democracy and education. An introduction to the philosophy of Education. New York: The MacMillan Company. 
Emmison, M., Butler, C. W., \& Danby, S. (2011). Script proposals: A device for empowering clients in counselling. Discourse Studies, 13(1), 3-26. https://doi.org/10.1177/1461445610387734

Eteläpelto, A., Vähäsantanen, K., Hökkä, P., \& Paloniemi, S. (2013). What is agency? Conceptualizing professional agency at work. Educational Research Review, 10, 45-65. https://doi.org/10.1016/j. edurev.2013.05.001

Giddens, A. (1991). Modernity and self-identity. Self and society in the late modern age. Polity Press.

Hodkinson, P., \& Sparkes, A. (1997). Careership: A sociological theory of career decision making. British Journal of Sociology of Education, 18(1), 29-44. https://doi.org/10.1080/0142569970180102

Honkasalo, V., Maiche, K., Ononera, H., Peltola, M., \& Suurpää, L. (2017). Nuorten turvapaikanhakijoiden elämää vastaanottovaiheessa [Young people seeking asylum]. Nuorisotutkimusverkosto

Hooley, T. (2014). The evidence base on lifelong guidance: A guide to key findings for effective policy and practice. EXTENDED SUMMARY. The European Lifelong Guidance Policy Network (ELGPN).

Hooley, T., \& Sultana, R. G., \& Thomsen, R. (2018). Career guidance for social justice. Contesting Neoliberalism. Routledge.

Hooley, T., Sultana, R. G., \& Thomsen, R. (2019a). Career guidance for emancipation. Reclaiming justice for multitude. Routledge.

Hooley, T., Sultana, R. G., \& Thomsen, R. (2019b). Representing problems, imagining solutions. emancipatory carer guidance for the multitude. In T. Hooley, R. G. Sultana, \& R. Thomsen (Eds.), Career guidance for emancipation. Reclaiming justice for multitude (pp. 1-13). Routledge.

Hooley, T. (2019). Riding the social justice wave: Where next for policy, practice and theory in career guidance? https://adventuresincareerdevelopment.wordpress.com/2019/10/23/riding-the-socia 1-justice-wave/.

Kerkkänen, H., \& Säävälä, M. (2015). Maahanmuuttajien psyykkistä hyvinvointia ja mielenterveyttä edistävät tekijät ja palvelut [Factors and services that promote mental well-being and mental health of immigrants]. Työ- ja elinkeinoministeriön julkaisuja 40/2015.

Kinnell, A.-M.K., \& Maynard, D. (1996). The delivery and receipt of safer sex advice in pretest counselling sessions for HIV and AIDS. Journal of Contemporary Ethnography, 24(4), 405-437. https://doi.org/10.1177/089124196024004002

Krivonos, D. (2019). Migrations on the edge of whiteness: Young Russian-speaking migrants in Helsinki, Finland. University of Helsinki. http://urn.fi/URN:ISBN:978-951-51-3400-4.

Kurki, T. (2019). Immigrant-ness as (mis)fortune?-Immigrantisation through integration policies and practices in education. University of Helsinki. http://urn.fi/URN:ISBN:978-951-51-4713-4.

Laros, A., Fuhr. T., \& Taylor, E. W. (Eds.). (2017). Transformative learning meets Bildung. An international exchange. International Issues in Adult Education series. Sense Publishers.

Määttä, M. (2019). Reforming youth transition support with the multi-agency approach?-A case study of the Finnish one-stop guidance centers. Sociologiga, 61, 2. https://doi.org/10.2298/ SOC1902277M

Peräkylä, A. (1995). AIDS counselling. Institutional interaction and clinical practice. Cambridge University Press.

Peräkylä, A., \& Vehviläinen, S. (2003). Conversation analysis and the professional stocks of interactional knowledge. Discourse \& Society, 14(6), 727-750. https://doi.org/10.1177/0957926503 0146003

Peräkylä, A., Antaki, C., Vehviläinen, S., \& Leudar, I. (Eds.). (2008). Analysing psychotherapy in practice. In Conversation analysis and psychotherapy. Cambridge: Cambridge University Press.

Pudlinski, C. (2012). The pursuit of advice on US peer telephone helplines: Sequential and functional aspects. In H. Limberg \& M. Locher (Eds.), Advice in discourse (pp. 253-252). John Benjamins.

Pälli, P., \& Lehtinen, E. (2014). Making objectives common in performance appraisal interviews. Language and Communication, 39, 92-108. https://doi.org/10.1016/j.langcom.2014.09.002

Romito, M. (2019). Career guidance and neoliberal rationality in Italian schools. In T. Hooley, R. G. Sultana, \& R. Thomsen (Eds.), Career guidance for emancipation. Reclaiming justice for multitude (pp. 98-115). Routledge.

Rose, N. (1999). Governing the soul. The shaping of the private self. Free Association Books.

Safran, J. D., Muran, C., Stevens, C., \& Rothman M. (2007). A relational approach to supervision: Addressing ruptures in the alliance. In C. A. Falender \& E. P. Shafranske (Eds.), Casebook for clinical supervision: A competency-based approach (pp. 137-157). American Psychological Association.

Savickas, M., Nota, L., Rossier, J., Dauwalder, J.-P., Duarte, M. E., Guichard, J., Soresi, S., van Esbroeck, R., \& van Vioannen, A. (2009). Life design. A paradigm for career construction 
in the 21st century. Journal of Vocational Behavior, 75, 239-250. https://doi.org/10.1016/j. jvb.2009.04.004

Schegloff, E. A. (2007). Sequence organization in interaction: A primer in conversation analysis (Vol. 1). Cambridge University Press.

Sidnell, J., \& Stivers, T. (Eds.). (2012). The handbook of conversation analysis. Wiley \& Blackwell.

Silverman, D. (1997). Discourses of counselling. HIV counselling as social interaction. SAGE.

Souto, A.-M. (2016). Etnistyvät toisen asteen koulutusvalinnat [How do ethnicity and racism shape young people's upper secondary school choices]. Nuorisotutkimus, 34(4), 47-59.

Souto, A.-M. (2020). Väistelevää ohjausta-Opinto-ohjauksen yksin jättävät käytänteet maahanmuuttajataustaisten nuorten parissa [Dodging practices in career guidance of migrant youth]. Kasvatus, 51(3), 317-329.

Souto, A-M., \& Vehviläinen, S. (2019). Miten opinto-ja uraohjaus kohtaa maahan muuttaneet nuoret? Kohti yhteiskunnallisesti tiedostavaa ohjausta. SETSTOP seminaari 3.4.2018 Itä-Suomen yliopisto. (How does study guidance encounter migrant young people? Towards societally conscious guidance. A conference presentation, University of Eastern Finland).

Strong, M., \& Baron, W. (2004). An analysis of mentoring conversations with beginning teachers: Suggestions and responses. Teaching and Teacher Education, 20(1), 47-57. https://doi. org/10.1016/j.tate.2003.09.005

Stevanovic, M., \& Peräkylä, A. (2012). Deontic authority in interaction: The right to announce, propose, and decide. Research on Language \& Social Interaction, 45(3), 297-321. https://doi. org/10.1080/08351813.2012.699260

Stokoe, E. (2012). Moving forward with membership categorization analysis: Methods for systematic analysis. Discourse Studies, 14(3), 277303. https://doi.org/10.1177/1461445612441534

Svinhufvud, K., \& Vehviläinen, S. (2013). Papers, documents, and the opening of an academic supervision encounter. Text \& Talk, 33(1), 139-166. https://doi.org/10.1515/text-2013-0007

Sultana, R. G. (2014). Career guidance for social justice in neoliberal times. In G. Arulmani, A. J. Bakshi, F. T. L. Leong, \& T. Watts (Eds.), Handbook of career development. International perspectives (pp. 317-334). Springer. https://link.springer.com/chapter/10.1007\%2F978 -1-4614-9460-7_18.

Thomsen, R. (2012). Career guidance in communities. Aarhus University Press.

Vehviläinen, S. (1999). Structures of counselling interaction. A conversation analytic study of counselling encounters in career guidance training. University of Helsinki, Department of Education.

Vehviläinen, S. (2001). Evaluative advice in educational counseling: The use of disagreement in the "stepwise entry" to advice. Research on Language and Social Interaction, 34(3), 371-398. https ://doi.org/10.1207/S15327973RLSI34-3_4

Vehviläinen, S. (2003). Avoiding providing solutions: Orienting to the ideal of student's self-directedness in counselling interaction. Discourse Studies, 5(3), 389-414. https://doi.org/10.1177/14614 456030053005

Vehviläinen, S. (2008). Identifying and managing resistance in psychoanalytic interaction. In A. Peräkylä, C. Antaki, S. Vehviläinen, \& I. Leudar (Eds.), Conversation analysis and psychotherapy (pp. 120-138). Cambridge University Press.

Vehviläinen, S. (2009). Student-initiated advice in academic supervision. Research on Language and Social Interaction, 42(2), 163-190. https://doi.org/10.1080/08351810902864560

Vehviläinen, S. (2009). Problems in the research problem: Criticism and resistance in academic supervision encounters. Scandinavian Journal of Educational Research, 6(2), 185-201. https:// doi.org/10.1080/00313830902757592

Vehviläinen, S. (2012). Question-prefaced advice in feedback sequences of Finnish academic supervisions. In H. Limberg \& M. A. Locher (Eds.), Advice in discourse (pp. 31-52). Pragmatics and beyond new series. John Benjamins. https://doi.org/10.1075/pbns.221.

Vehviläinen, S. (2014). Ohjaustyön opas. Yhteistyössä kohti toimijuutta [Guide to guidance. Together towards agency]. Gaudeamus.

Vehviläinen, S. (2018). The locus of power in counselling interaction. In Conference presentation. Counselling for solidarity, social justice, and dialogue; UNESCO UNITWIN conference, 24-25 May 2018. Wroclaw, Poland.

Vehviläinen, S. (2020). \#Paraskoulu-hankkeen arviointia ohjausosaamisen näkökulmasta [Evaluating the \#BestSchool project from the guidance expertise angle]. \#Paraskoulu-hankkeen loppuraportti. 
Vehviläinen, S., \& Löfström, E. (2016). 'I wish I had a crystal ball': Discourses and potentials for developing academic supervising. Studies in Higher Education, 41(3), 508-524. https://doi. org/10.1080/03075079.2014.942272

Vehviläinen,, S., Peräkylä, A., Antaki, C., \& Leudar, I. (2008). A review of conversational practices in psychotherapy. In A. Peräkylä, C. Antaki, S. Vehviläinen, \& I. Leudar (Eds.), Conversation analysis and psychotherapy (pp. 188-197). Cambridge University Press.

Vehviläinen, S., \& Souto, A.-M. (2018). Ohjaus yhteiskunnassa: ohjausteoriat ja nuorisotutkimus dialogissa [Guidance in society: guidance and counselling theories meet youth studies]. Aikuiskasvatuksen tutkimuspäivät 15.-16.2.2018 Itä-Suomen yliopisto.

Vehviläinen, S., \& Svinhufvud, K. (2018). Työskentelyongelman määrittely opintopsykologin vastaanotolla [Determining the working problem at study psychologists' consultations]. Psykologia, 53(05-06), 364-448.

Vine, B., Holmes, J., \& Marra, M. (2012). Mentoring migrants: Facilitating the transition to the New Zealand workplace. In H. Limberg \& M. A. Locher (Eds.), Advice in discourse (pp. 145-166). John Benjamins.

Voutilainen, L., Peräkylä, A., \& Ruusuvuori, J. (2010). Recognition and interpretation: Responding to emotional experience in psychotherapy. Research on Language and Social Interaction, 43(1), 85-107. https://doi.org/10.1080/08351810903474799

Waring, H. Z. (2005). Peer tutoring in a graduate writing center: Identity, expertise and advice resisting. Applied Linguistics, 26(2), 141-168.

Waring, H. Z. (2007). The multi-functionality of accounts in advice giving. Journal of Sociolinguistics, 11(3), 367-369. https://doi.org/10.1111/j.1467-9841.2007.00328.x

Waring, H. Z. (2012). The advising sequence and its preference structures in graduate peer tutoring at an American university. In H. Limberg \& M. A. Locher (Eds.), Advice in discourse. Pragmatics and beyond new series (pp. 97-118). John Benjamins.

Weiste, E. (2015). Describing therapeutic projects across sequences: Balancing between supportive and disagreeing interventions. Journal of Pragmatics, 80, 22-43. https://doi.org/10.1016/j.pragm a.2015.02.001

Weiste, E., \& Peräkylä, A. (2014). Prosody and empathic communication in psychotherapy interaction. Psychotherapy Research, 24(6), 687-701. https://doi.org/10.1080/10503307.2013.879619

Weiste, E., Vehviläinen, S., Leino, T., \& Laitinen, J. (2018). Ohjauksen vuorovaikutuskäytänteet työterveystarkastuksissa: vertailu ennen koulutusinterventiota ja sen jälkeen. Psykologia, 53(5-6), 328446. (Guidance practices in occupational health checks: Comparison before and after an training intervention).

Wilkinson, S., \& Kitzinger, C. (2003). Constructing identities: A feminist conversation analytic approach to positioning in action. In R. Harré \& F. M. Moghaddam (Eds.), The self and others: Positioning individuals and groups in personal, political, and cultural contexts (pp. 157-180). Greenwood Publishing Group.

Publisher's Note Springer Nature remains neutral with regard to jurisdictional claims in published maps and institutional affiliations. 